\title{
Ponteando opostos e especulando ideia: Riobaldo e a angústia da falta de sentido
}

\author{
"Sorting out contraries" and "speculating idea": \\ Riobaldo and the anxiety of senselessness
}

\section{Claudia Campos Soares}

Universidade Federal de Minas Gerais - UFMG - Belo Horizonte - Minas Gerais - Brasil

\begin{abstract}
Resumo: Riobaldo, o narrador-protagonista de Grande sertão: veredas, é um homem perturbado por lembranças de um passado que não compreende. Tendo vivido na juventude experiências cujo sentido não consegue alcançar, dedica-se agora, na velhice, a procurar, para elas, explicações tranquilizadoras. Riobaldo busca verdades e certezas, entretanto o seu "gosto de especular ideia", para usar suas próprias palavras, cria muitas dificuldades ao cumprimento desse objetivo. Acompanhando o curso das reflexões do ex-jagunço, pode-se perceber que uma das coisas que "especular ideia" significa é problematizar, uma por uma, todas as proposições alcançadas em cada momento da reflexão no instante mesmo em que se propõem, instaurando um processo de mudança incessante que impede a fixação de qualquer sentido último. Contribui, também, na construção desse efeito de indeterminação de sentidos a intensa utilização de paradoxos no livro. Para o desenvolvimento dessa questão, discutiu-se alguns aspectos da complexa relação entre liberdade, destino e acaso que se dá em Grande sertão: veredas.
\end{abstract}

Palavras-chave: Grande sertão: veredas. Guimarães Rosa. Estratégias de indeterminação. Paradoxo. Liberdade, destino e acaso.

\begin{abstract}
Riobaldo, the protagonist narrator of Grande sertão: veredas, is a man disturbed by recollections of a past he does not understand. In his youth he experienced things that he could not grasp. Now as an old man he devotes himself to seeking comforting explanations for those events. Riobaldo tries to find truths and certainties; however, his taste for, in his own words "speculating idea ", creates a lot of difficulties for him to achieve this goal. Following his thoughts, the reader can perceive that "speculating idea" means among other things to problematize, one by one, all the propositions of his reflections. This tendency engenders an uninterrupted process of change, which prevents him from attaching any enduring sense to his thoughts. The intense use of paradoxes in the novel contributes to this effect as well. To approach this question here a discussion of some aspects of the complex relationship between freedom, fate, and chance present in Grande sertão: veredas was carried out.
\end{abstract}

Keywords: Grande sertão: veredas. Guimarães Rosa. Strategies of indeterminacy. Paradox. Freedom, fate, chance. 
Uma das formas de se ver a narração que se dá em Grande sertão: veredas é como demanda de sentido. Assombrado por lembranças perturbadoras de sua juventude, o ex-jagunço Riobaldo, narrador de sua própria história, o faz para compreender: seu objetivo, várias vezes explicitado no livro, é o de estabelecer, para o "sucedido desgovernado" de sua travessia, uma organização inteligível, e, assim, aplacar a angústia da falta de sentido. (p.99) ${ }^{1}$ Afirma ele: "Eu queria decifrar as coisas que são importantes. (...) Queria entender do medo e da coragem, e da gã que empurra a gente para fazer tantos atos, dar corpo ao suceder." (p.100)

A angústia pela falta de sentido se manifesta, por exemplo, no afã com que o Riobaldo recorre aos mais variados suportes religiosos. Afirma ele:

O que mais penso, testo e explico: todo-omundo é louco. O senhor, eu, as pessoas todas. Por isso é que se carece principalmente de religião: para se desendoidecer, desdoidar. Reza é que sara da loucura. No geral. Isso é que é a salvaçãoda-alma... Muita religião, seu moço! Eu cá, não perco ocasião de religião. Aproveito de todas. Bebo água de todo rio... Uma só pra mim é pouca, talvez não me chegue. Rezo cristão, católico, embrenho a certo; e aceito as preces de compadre meu Quelemém, doutrina dele, de Cardéque. Mas, quando posso, vou no Mindubim, onde um Matias é crente, metodista: a gente se acusa de pecador, lê alto a Bíblia, e ora, cantando hinos belos deles. (16)

O ex-jagunço se apega a essa multiplicidade de religiões porque busca um sistema de valores e referências que lhe permita explicar o que, através dele, se revelaria como o desconcerto apenas aparente do mundo. O próprio fato de recorrer a tantas religiões, entretanto, indica que em nenhuma ele encontra as respostas tranquilizadoras que procura. E o acúmulo também não preenche a falta. Enuncia-o a seguinte afirmação de Riobaldo, que se segue ao trecho transcrito acima: "Tudo me quieta,

\footnotetext{
${ }^{1}$ O trecho é de Grande sertão: veredas. (ROSA, 2006) As citações extraídas do livro virão indicadas no corpo do trabalho apenas pelos números de página, entre parêntesis, na referida edição.
}

me suspende. Qualquer sombrinha me refresca. Mas é só muito provisório." $(16)^{2}$

A busca de certezas do ex-jagunço é, como se vê, contraposta à consciência da impossibilidade delas, o que gera suspensão de sentido, indeterminação. Mesmo porque, em muitos momentos, as reflexões de Riobaldo cumprem a trajetória de um círculo vicioso. Assim se dá em relação à questão da religião: imediatamente após enunciar que é fugaz o conforto que encontra em todas elas, ou seja, após declarar que elas não satisfazem a sua necessidade de certezas, ele volta a afirmar a "virtude de poder" das orações:

Olhe: tem uma preta, Maria Leôncia, longe daqui não mora, as rezas dela afamam muita virtude de poder. Pois a ela pago, todo mês encomenda de rezar por mim um terço, todo santo dia, e, nos domingos, um rosário. Vale, se vale. (...) E estou, já mandei recado para uma outra, do Vau-Vau, uma Izina Calanga, para vir aqui, ouvi de que reza também com grandes meremerências, vou efetuar com ela trato igual. Quero punhado dessas, me defendendo em Deus, reunidas de mim em volta... Chagas de Cristo! (16)

Como observou Derrida, "a coerência na contradição exprime a força de um desejo" (2005, p.230-231): o do "significado transcendental"; 3 no caso de Riobaldo, o sentido luminoso, unívoco, definitivo, que lhe permitiria encontrar uma coerência nos acontecimentos experimentados enquanto "sucedido desgovernado". Nas palavras do próprio ex-jagunço, o que ele busca é a "verdadeira lâmpada de Deus, a lisa e real verdade". (p.343)

A esse respeito, vale chamar a atenção também para a admiração que Riobaldo nutre por seu "Compadre Quelemém", que conhecera por indicação de Zé Bebelo quando atravessava a grave crise pessoal pela qual foi acometido depois da morte de Diadorim. Quelemém, homem profundamente

\footnotetext{
2 Alguns aspectos dessa questão foram discutidos em SOARES, 2014.

${ }^{3} \mathrm{O}$ significado transcendental, nas palavras de Terry Eagleton, é "uma palavra, presença, essência, verdade ou realidade derradeira, que agirá como base de todo o nosso pensamento, linguagem e experiência"; "signo que dará significação a todos os outros"; "significação básica, inquestionável, para a qual todos os signos podem se voltar". (EAGLETON, 1997, p.180) Significado transcendental é algo próximo de "centro", outra noção muito importante para Derrida, como se sabe.
} 
religioso, praticante do espiritismo kardecista, ouvira, aconselhara e confortara Riobaldo na ocasião. E continuou fazendo-o vida afora. O ex-jagunço, desde então, frequentemente discute com ele as complexas questões que o inquietam e sempre tem em alta consideração as posições do "compadre", como o indicam os verbos que costuma utilizar para enuncialas. Afirma Riobaldo, por exemplo: "A gente viemos do inferno - nós todos - compadre meu Quelemém instrui." (p.48 - grifo meu) Em outro momento: "Compadre meu Quelemém, muitos anos depois, me ensinou que todo desejo a gente realizar alcança (...). Diz ele; eu creio. (p.153 - grifos meus)

Ainda nas palavras do ex-jagunço, seu compadre Quelemém "nunca fala vazio, não subtrata" (p.23), e "está certo sempre" (p.150); entretanto, a posição de Riobaldo diante da confiança sólida de Quelemém nos preceitos de sua religião é frequentemente problematizadora. É o que se percebe, por exemplo, quando o ex-jagunço relata a conversa que teve com o compadre a respeito de dois casos: o do valentão Aleixo e seus filhos e do menino Valtei e seus pais. O primeiro personagem, apesar de ser o "homem de maiores ruindades calmas que já se viu", era "afamilhado, tinha filhos pequenos; aqueles eram o amor dele, todo, despropósito.” (p.12) A certa altura da vida, os filhos do Aleixo foram ficando todos cegos, o que provocou uma transformação profunda no comportamento do pai, que, desde então,

demudou completo - agora vive da banda de Deus, suando para ser bom e caridoso em todas suas horas da noite e do dia. Parece até que ficou o feliz, que antes não era. Ele mesmo diz que foi um homem de sorte, porque Deus quis ter pena dele, transformar para lá o rumo de sua alma. (p.12)

Riobaldo se indigna diante dessa posição do ex-valentão, questionando: "Se sendo castigo, que culpa das hajas do Aleixo aqueles meninozinhos tinham?!" E prossegue: "Compadre meu Quelemém reprovou minhas incertezas. Que, por certo, noutra vida revirada, os meninos também tinham sido os mais malvados, da massa e peça do pai, demônios do mesmo caldeirão de lugar. (...)" (p.13) Na segunda história, os pais se transformam em direção oposta: de tanto castigarem o filho Valtei, "gostoso de ruim de dentro do fundo das espécies de sua natureza" (p.13), Pedro Pindó e a mulher "se habituaram de nele bater, de pouquinho em pouquim foram criando nisso um prazer feio de diversão - como regulam as sovas em horas certas confortáveis, até chamam gente para ver o exemplo bom." Riobaldo, que se apieda do sofrimento do menino ("Ah, mas, acontece, quando está chorando e penando, ele sofre igual que se fosse um menino bonzinho..."), obtém de Quelemém uma explicação que segue o mesmo raciocínio da anterior: O menino "devia, em balanço, terríveis perversidades. Alma dele estava no breu. (...) E, agora, pagava." Riobaldo, entretanto, conclui a narração das duas histórias com a seguinte consideração: "e no começo - para pecados e artes, as pessoas - como por que foi que tanto emendado se começou? Ei, ei, aí todos esbarram. Compadre meu Quelemém, também." (p.14)

Esse tipo de procedimento, duas vezes apontado aqui, é recorrente em GSV. O narradorprotagonista do romance de Guimarães Rosa propõe certezas tranquilizadoras - o saber seguro e certo das religiões ou de Quelemém, por exemplo -, mas assume uma postura de dúvida sistemática diante de quaisquer verdades estabelecidas, o que faz com que elas acabem por não resistir ao seu exame. Nenhuma certeza se sustenta por muito tempo em Grande sertão: veredas porque o desejo logocêntrico de Riobaldo convive com seu "gosto de especular ideia", como ele mesmo afirma a certa altura.

De primeiro, eu fazia e mexia, e pensar não pensava. Não possuía os prazos. Vivi puxando difícil de difícel, peixe vivo no moquém: quem mói no asp'ro, não fantasêia. Mas, agora, feita a folga que me vem, e sem pequenos dessossegos, estou de range rede. $\mathrm{E}$ me inventei neste gosto de especular ideia. (p.10)

Nesse trecho, Riobaldo se apresenta como homo actuandi no passado e homo cogitandi no presente, para utilizar os termos de José Carlos Garbuglio. (1983, p.424) O ex-jagunço afirma que, no tempo em que se dava a experiência relatada, estava totalmente absorvido pelas exigências da vida e da sobrevivência, e não havia espaço em sua vida para a reflexão. Agora, entretanto, retirado do redemoinho 
da travessia e levando vida estável e pacata como fazendeiro às margens do São Francisco, dispõe de tempo ocioso para refletir sobre as experiências perturbadoras do passado em busca de compreendêlas. Riobaldo, que já foi chamado de "filósofo rústico" por um crítico (BRUYAS, 1983, p.471), se dedica, em sua velhice, a examinar, demorada e continuamente, em seus mais diversos aspectos e manifestações, "as coisas que são importantes". E tenta fazê-lo de uma perspectiva lógica e racional, mesmo quando o assunto é religião, como o demonstra o trecho em que problematiza a doutrina da transmigração das almas em que crê seu compadre Quelemém. É o que se percebe também neste trecho, bastante conhecido do livro, em que Riobaldo, em suas próprias palavras, vai "ponteando opostos":

eu careço de que o bom seja bom e o rúim ruim, que dum lado esteja o preto e do outro o branco, que o feio fique bem apartado do bonito e a alegria longe da tristeza! Quero os todos pastos demarcados... (p.221)

O procedimento de Riobaldo nesse trecho é o de propor significados excludentes em série, como se estivesse preparando uma escolha ou uma definição, ou seja, baseando-se num sistema lógico onde vigora a regra do "ou isso ou aquilo": o ex-jagunço procura identidades claramente delimitadas e fixas, que se estabeleçam por oposição a outras, igualmente fixas e delimitadas. Vale lembrar, entretanto, que aqui também logo se instaura o curto-circuito. É o que demonstra a continuação da citação: "Como é que posso com este mundo? A vida é ingrata no macio de si; mas transtraz a esperança mesmo do meio do fel do desespero. Ao que, este mundo é muito misturado..." (p.221) O problema para Riobaldo, portanto, é que o "mundo misturado" não funciona segundo a lógica das identidades e oposições, o aparato binário não alcança sua complexidade. No mundo misturado, nenhuma regra ou critério seguro permite distinguir, de modo inequívoco, o bom do ruim, o preto do branco, o bonito do feio e a alegria da tristeza.

Pelo que foi discutido aqui, pode-se dizer que uma das coisas que "especular ideia" significa é problematizar, uma por uma, todas as posições alcançadas em cada momento da reflexão no instante mesmo em que se propõem, instaurando um processo de mudança incessante que impede a fixação de qualquer sentido último. Afirmando verdades para problematizar cada uma delas imediatamente depois de propô-las, numa espécie de dialética sem síntese, Riobaldo, em suas as tentativas de determinação, acaba por chegar ao ponto cego, ao impasse, à aporia, ao lugar a partir do qual não é possível ir adiante. Seguindo o fio da lógica, o exjagunço acaba, portanto, conduzido a regiões alógicas e, assim, experimenta mais a indeterminação do que a determinação, apesar de seus esforços em contrário.

É nesse sentido que atua também a altíssima incidência do enunciado paradoxal no livro. Tal como a fórmula de Bartleby, de que fala Deleuze, o paradoxo funciona como uma agramaticalidade, algo que escapa, que não se submete às regras de uma gramática (1997, p.86), compreendendo-se gramática como modelo de regras e procedimentos a partir do qual se podem operar variações infinitas. $O$ universo da gramática, edificado sobre princípios lógicos e racionais, se permite, no plano morfológico e sintático, a afirmação de sentidos opostos como igualmente válidos, não 0 permite no plano semântico. Ou seja, o paradoxo se constitui a partir de possibilidades da linguagem, mas, partindo daí, instaura agramaticalidades, cria impossíveis semânticos. Assim, vai também de encontro à doxa, ainda nas palavras de Deleuze, essa "espécie de 'guarda-sol' que nos protege do caos" (1992, p.238). A doxa trabalha com identidades fixas, estabelecidas a partir do princípio da "indicação ou designação" que, segundo Deleuze, "exprime-se (...) sob a forma: ‘é isto', 'não é isto'” (DELEUZE, 2009, p.13) - e da "faculdade de identificação", que é o que "permite relacionar uma diversidade qualquer à forma do Mesmo" (Idem, p.80). A identificação é o que possibilita remeter entidades similares ou próximas a uma entidade maior que as congrega num conjunto; conjunto esse que se opõe, por sua vez, a outros conjuntos compostos por outras entidades igualmente similares ou próximas entre si. Riobaldo gostaria de 
organizar a experiência nesses termos, mas seu "gosto de especular ideias" não o permite, como foi discutido, e é na forma do paradoxo que ele é frequentemente obrigado a se expressar, justamente o paradoxo, que "tem e por característica o fato de ir em dois sentidos ao mesmo tempo e tornar impossível uma identificação, colocando a ênfase ora num ora noutro desses efeitos" (DELEUZE, 2009, p.78). ${ }^{4}$

Um dos paradoxos mais conhecidos de Grande sertão: veredas aparece no seguinte trecho, onde Riobaldo continua discutindo a questão da bondade e da maldade das pessoas e as posições e crenças de Quelemém:

o que gasta, vai gastando o diabo de dentro da gente, aos pouquinhos, é o razoável sofrer. E a alegria de amor - compadre meu Quelemém, diz. Família. Deveras? É, e não é. O senhor ache e não ache. Tudo é e não é... (p.11)

Observa-se aqui a mesma estratégia de afirmação e subsequente problematização de sentidos dados por parte de Riobaldo que se vem discutindo aqui: o ex-jagunço apresenta uma posição de Quelemém (que ele costuma dizer que "está certo sempre", lembremo-nos) e, logo a seguir, o questionamento dessa mesma posição. Ele o faz inicialmente pela expressão direta da dúvida acerca da validade do "saber" que a primeira afirmação enuncia (“Deveras?"); e, a seguir, por meio de três enunciações paradoxais. O primeiro e o segundo paradoxos ("É, e não é" e "O senhor ache e não ache"), denunciam a visão bipolar como insuficiente para dar conta da complexidade e da diversidade dos comportamentos das pessoas no que se refere às noções de bondade e maldade. O terceiro paradoxo ("Tudo é e não é" - grifo meu) generaliza o problema, atribuindo a condição de indeterminação a todas as coisas. Assim, Riobaldo apresenta a lógica do "ou isso ou aquilo" como pressuposto precário para a reflexão sobre qualquer assunto inerente à travessia. Os paradoxos do Grande sertão estão sempre a nos

\footnotetext{
4 Impossibilita também, obviamente, a "indicação", ou "designação", uma vez que o paradoxo afirma que "isto" é "aquilo".
}

"recordar os limites, explícitos ou não, de um jogo de linguagem estabelecido, e [a nos] mostrar que esses decretos são decisões e não verdades." (LYOTARD, 1979, p.184) E, se "tudo é e não é", a única verdade possível é que não há verdades.

O curto circuito de sentido que se observa aí assemelha-se ao que se dá na seguinte afirmação de Riobaldo, que se refere à relação entre destino e liberdade individual, outra "coisa importante" que o ex-jagunço gostaria de "decifrar": "Eu estava indo a meu esmo." (p.104). Nessa frase paradoxal, Riobaldo assevera e, ao mesmo tempo, nega a sua liberdade em determinar os próprios caminhos. Aí, a ideia de andar a esmo (vale dizer, sem direção, sem destino, sem propósito) é problematizada por um pronome possessivo que traz o traço da determinação do eu que a enuncia, gerando uma zona de ambiguidade que impede o estabelecimento de um sentido final.

A questão se coloca porque Riobaldo gostaria de ter controle absoluto sobre sua vida, como ele mesmo o explicita: "Ser dono definitivo de mim, era o que eu queria, queria." (p.38) Ele, entretanto, não o consegue, por muitos motivos. Um deles é a imprevisibilidade própria da travessia, onde, independentemente (ou a despeito) de qualquer planejamento, irrompe o acaso que tudo transforma. Afirma ele a certa altura:

Na minha [vida], agora é que vejo, as coisas importantes, todas, em caso curto de acaso foi que se conseguiram - pelo pulo fino de sem ver se dar - a sorte momenteira, por cabelo por um fio, um clim de clina de cavalo. Ah, e se não fosse, cada acaso, não tivesse sido, qual é então que teria sido o meu destino seguinte? Coisa vã, que não conforma respostas. As vezes essa ideia me põe susto. (p.126)

Vários críticos chamaram a atenção para a importância do acaso na obra de Guimarães Rosa. Alfredo Bosi, por exemplo, afirma que, no universo rosiano, mais especificamente nos contos de Primeiras estórias, o "acaso, o imprevisto, o universo semântico do 'de repente' entram no meio dos episódios e operam mudanças qualitativas no destino dos personagens". (BOSI, 1988, p.23) Benedito Nunes foi outro crítico que chamou a atenção para a relevância da questão. Segundo ele, a existência dos 
personagens de Guimarães Rosa é marcada por "lances aleatórios de jogo", que vão determinando seus "destinos itinerantes". (NUNES, 2013, p.83) Para ambos os críticos, entretanto, o acaso só aparentemente opera de forma aleatória. Benedito Nunes, por exemplo, afirma:

Misto de acaso e necessidade, a ação dos personagens (...) segue, em geral, de maneira ostensiva ou encoberta, a linha itinerante de caminhos que se apartam e se entrecruzam, para se unirem depois, produzindo, pela convergência de causas mínimas, imprevisíveis, circunstanciais, um efeito único, que parece pré-ordenado por uma razão (logos) exterior aos atos humanos. As coisas e os animais participam de um encadeamento secreto de causas... (NUNES, 2013, p.81, grifo meu)

No trecho acima, Nunes se refere especificamente a Sagarana, mas seu estudo como um todo objetiva demonstrar como a questão - que se encontra "latente na forma de sucessos, conflitos, acontecimentos trágicos ou cômicos" nesse primeiro livro de Rosa (NUNES, 2013, p.81) - se desenvolve e estende para toda a obra do autor. Para o crítico, a existência dos personagens rosianos, em geral, é determinada pelo que parecem ser "lances do acaso", mas eles só aparentemente são resultado de coincidências e circunstâncias ocasionais. O acaso seria, na verdade, instrumento de que o destino - a "razão (logos)", esse "encadeamento secreto de causas" - se vale para se cumprir.

Bosi vê a questão de forma semelhante, pelo menos no que se refere ao aspecto do problema que cabe discutir aqui. Para o crítico, o acaso é "aquele reino de incertos sucessos que desde tempos imemoriais se confia aos desígnios da divindade. Esta, sem previsão alguma de nossa parte, intervém no curso regular das causas e efeitos", e opera mudanças radicais no destino dos personagens. (BOSI, 1988, p.24) Isso costuma permitir a eles superar o estado de carência que os limita no início dos contos. Bosi acredita que, no mundo de Guimarães Rosa, a "ordem do transcendente" "abre horizontes sem fim", e, "no devir da fantasia, alguma coisa sempre pode acontecer." (1988, p.23) Para o crítico, portanto, em Primeiras estórias vigoraria uma visão "providencial" da existência, pois o acaso pode trazer a superação do estado de carência, de necessidade, recompensando a "vontade profunda, gestada no coração das criaturas que esperam." (1988, p.25) Bosi afirma ainda que, no universo rosiano, "o desnorte dá no norte. (...) porque o mundo, o vasto mundo desconhecido, é palmilhado por um ser que busca, um vivente que quer; há um sentido final, um telos." (1988, p.30)

A visão que este trabalho propõe não vê a possibilidade de nenhum telos, de nenhuma razão superior dando sentido aos acontecimentos, nenhum logos, pelo menos não no que se refere a Grande sertão: veredas - e esse é justamente um dos motivos da angústia de Riobaldo, que, por estar sempre problematizando verdades estabelecidas pelo senso comum, pressupostos lógicos e verdades transcendentais, acaba frequentemente se sentindo da maneira como enuncia neste trecho: "Demais é que se está: muito no medo de nada." (p.210)

No romance de Guimarães Rosa, o acaso é o que traz o evento, ou acontecimento, no sentido em que Derrida utiliza o termo: o que irrompe sem ser esperado, o absolutamente fortuito, inopinado, acidental, casual. O evento vem do futuro, nada no presente o indica, ele está fora de qualquer horizonte de expectativas, e, portanto, de qualquer possibilidade de controle: não é possível preveni-lo, alterá-lo, fugir ou se defender dele. O evento "excede ao cálculo, às regras, aos programas, às antecipações" (DERRIDA 2007, p.55); ele é aquilo sobre o qual "nenhum programa, nenhuma máquina (...) irá jamais se fechar". (BENNINGTON, 1996, p.19)

É com esse tipo de acaso que Riobaldo está sempre se defrontando em sua travessia. Justo ele que tenta, de todas as formas, tomar as rédeas da vida em suas mãos, submetê-la o controle do cálculo - tem que se haver recorrentemente com o acontecimento que, a despeito de sua imprevisibilidade e casualidade, pode imprimir rumos radicalmente novos a ela. Tal é o caso de seu primeiro encontro com Diadorim quando eram ambos meninos. Riobaldo se encontrava na venda do porto do De-Janeiro pedindo esmolas a mando de sua mãe, 
que, devido a uma grave doença que acometeu o filho, fez a promessa de reunir uma certa quantia em dinheiro para oferecer à divindade de sua devoção caso ele se salvasse. Aquele que, neste momento, ainda não é apresentado como Diadorim, mas como "o Menino", estava ali em posição radicalmente diversa. De família de posses, acompanhava o tio que fora à venda comprar arroz, uma vez que, por motivo de falecimento da mulher do fazendeiro, não se plantara o cereal na fazenda de sua família naquele ano. ${ }^{5}$ Se Riobaldo não tivesse adoecido; ou se sua mãe não tivesse feito nenhuma promessa; ou se tivesse feito uma promessa diferente; ou se, por algum motivo, Riobaldo não tivesse ido esmolar naquele dia; se tivesse chegado mais tarde; ou ido embora mais cedo; se já tivesse conseguido quantia suficiente àquela altura e não precisasse esmolar mais...; ou então se a tia de Diadorim não tivesse morrido; se o tio não tivesse ido naquele dia; se Diadorim não o tivesse acompanhado; se tivessem tido algum problema no caminho e chegassem depois de Riobaldo ir embora...; enfim, se as coisas não tivessem se dado exatamente como se deram, o encontro entre os dois meninos poderia não ter acontecido. E essas são apenas algumas das circunstâncias sabidas do encontro, há inúmeras outras, incognoscíveis em sua totalidade. Um evento, para utilizar uma imagem de Foucault, é um "nó numa rede" (FOUCAULT, 2010, p.26): impossível proceder ao levantamento das causas que o provocaram, elas são virtualmente infinitas, sempre haverá uma causa anterior a qualquer "causa primeira".

Coisa muito semelhante ocorre quando os meninos, agora adultos, se reencontram, novamente por acaso, muito tempo depois. Após fugir do bando de Zé Bebelo e vagar pelo sertão por algum tempo, Riobaldo hospeda-se na casa de Malinácio, pai de uma mulher casada com quem, na ausência do marido, o ex-professor de Zé Bebelo passara a noite anterior. Riobaldo estava ali esperando, justamente, por sinais da mulher que indicassem que o marido

\footnotetext{
${ }^{5} \mathrm{O}$ trecho sugere ser um costume sertanejo não se plantar arroz quando falecem certos membros da família dos fazendeiros, entretanto a relação entre as duas coisas não é esclarecida no romance.
}

tornara a sair para que ele pudesse se encontrar novamente com ela. Enquanto isso, entretanto, é surpreendido pela chegada do "Menino", agora o jagunço Reinaldo.

Tanto o primeiro quanto o segundo encontros vieram sem nenhum aviso, de forma totalmente imprevista. A despeito de seu caráter fortuito, entretanto, são eventos que tiveram o poder de transformar profundamente o destino de Riobaldo. Como ele mesmo o sugere em trecho anteriormente citado, sua vida poderia ter sido (ou necessariamente teria sido) radicalmente diferente se os encontros com Diadorim não houvessem ocorrido. Sabemos, por exemplo, que Riobaldo só se tornou jagunço para ficar próximo do amigo tão especial. É por Diadorim que e entra no bando e pelo mesmo motivo lá permanece. Importante lembrar que, quando passa a acompanhar o amigo e entra no bando cujo subchefe era o justamente o Hermógenes, "o homem de maiores ruindades calmas que já se viu", ele acabara de fugir do bando de Zé Bebelo, entre outros motivos, por desidentificação em relação à violência própria ao mundo jagunço. Afirma ele: "eu reprovava aquilo: de se ir, com tanta maioria e largueza, matando e prendendo gente, na constante brutalidade." (p.135) Quando muda de lado, Riobaldo continua desaprovando a crueldade arbitrária e sem propósito, que vê encarnada, principalmente, na figura do Hermógenes. Demonstra de forma bastante determinante que Riobaldo não se sente completamente integrado ao bando o fato de ele não partilhar com os companheiros a postura de obediência cega a regras que, aos outros, parecem inquestionáveis, nem a quase idolatria de todos ao chefe maior, Joca Ramiro. Afirma ele, por exemplo: "Por que que era que todos davam assim tantas honras a Joca Ramiro, esse louvo sereno, com doado? Isso meio me turvava." (p.231-232)

Em inúmeros outros momentos explicita-se a fragilidade do sentimento de pertença de Riobaldo em relação ao grupo. Entretanto, apesar disso, ele não consegue abandoná-lo; ou melhor, não consegue abandonar Diadorim. Nem mesmo depois de conhecer Otacília, que também passou a representar 
algo de muito importante para ele: a possibilidade de uma vida sem guerra e sem maiores conflitos interiores. ${ }^{6}$ Riobaldo sempre se debateu em dúvidas entre seu "amor de prata" e "seu amor de ouro", como, certa vez, nomeou o sentimento que nutria por Otacília e Diadorim. (p.52) O ex-jagunço não especifica a qual de seus dois amores se refere cada atributo, mas pode indicar uma possibilidade o fato de ele ter sempre, o quanto isso foi possível, escolhido acompanhar Diadorim. Riobaldo afirma que quando estava com o bando, longe de Otacília, "Pensava nela. Às vezes menos, às vezes mais, consoante é da vida. Às vezes me esquecia, às vezes me lembrava. Foram esses meses, foram anos. Mas Diadorim, por onde queria, me levava." (p.198) Como se vê, para o então jagunço, seguir Diadorim não dependia de sua vontade, era antes um imperativo de alguma outra ordem, contra o qual ele não podia lutar: "Por que era que eu precisava de ir por adiante, com Diadorim e os companheiros, atrás de sorte e morte, nestes Gerais meus? Destino preso." (p.198) "E eu - como é que posso explicar ao senhor o poder de amor que eu criei? Minha vida o diga. Se amor? Era aquele latifúndio. Eu ia com ele até o rio Jordão... Diadorim tomou conta de mim." (p.193)

Riobaldo se sente ligado ao amigo de forma indissolúvel ("destino preso"), como que por uma espécie de possessão ("Diadorim tomou conta de mim") contra a qual ele nunca pôde lutar. ${ }^{7}$ Mesmo depois de tantos anos, o ex-jagunço continua a ser assombrado pelo fantasma de Diadorim. O caráter incompreensível daquela "mandante amizade", para além de qualquer "preceito" (p.200), é uma das principais questões para as quais Riobaldo busca esclarecimento ao contar sua história para o doutor. $\mathrm{E}$ tudo isso resultou de um encontro casual, fruto somente do acaso. A impossibilidade de entender o (não)sentido de tudo isso perturba profundamente o ex-jagunço:

\footnotetext{
${ }^{6}$ Essa questão foi discutida em mais detalhes em SOARES, 2014.

${ }^{7}$ Obviamente, outro motivo porque não consegue ser senhor de si é esse "amor mesmo amor, mal encoberto em amizade", contra o qual Riobaldo muito lutou sem nenhum sucesso. (289)
}

Agora, que o senhor ouviu, perguntas faço. Por que foi que eu precisei de encontrar aquele Menino? Toleima, eu sei. Dou, de. O senhor não me responda. (...) Mas, onde é bobice a qualquer resposta, é aí que a pergunta se pergunta. Por que foi que eu conheci aquele Menino? O senhor não conheceu, compadre meu Quelemém não conheceu, milhões de milhares de pessoas não conheceram. O senhor pense outra vez, repense o bem pensado: para que foi que eu tive de atravessar 0 rio, defronte com 0 Menino? (...) Mas, para quê? por quê? Eu estava no porto do De-Janeiro, com minha capanguinha na mão, ajuntando esmolas para o Senhor Bom-Jesus, no dever de pagar promessa feita por minha mãe, para me sarar de uma doença grave. Deveras se vê que o viver da gente não é tão cerzidinho assim? $(109-110)$

A insistência da pergunta pelo sentido do encontro com Diadorim-Menino - cinco vezes colocada, com variações, num curtíssimo trecho do livro - a despeito da consciência de que a obtenção de uma resposta seja impossível (a mesma estratégia de afirmar e negar a seguir, de que se tem falado aqui), dá conta da perplexidade de Riobaldo em relação ao caráter absolutamente circunstancial de um acontecimento que foi capaz de determinar tão profundamente a sua vida.

O que se problematiza aqui, portanto, é também a ideia de "liberdade individual". Trata-se de uma questão recorrente na obra de Guimarães Rosa. Ela é muito importante, por exemplo, em "O recado do morro", novela de Corpo de baile, onde, pela forma como se articulam os acontecimentos na estória, sugere-se que uma montanha, o Morro da Garça, tenha enviado um recado ao guia-enxadeiro Pedro Orósio, alertando-o sobre um plano de assassinato que está sendo urdido contra ele e do qual ele não tem a mínima suspeita. Da compreensão desse recado depende, portanto, a vida do protagonista, que, se conseguir ouvi-lo, talvez possa responder ao destino que está sendo traçado para (contra) ele. O recado é sete vezes retransmitido por sete recadeiros, todos em alguma medida marginais em relação ao mundo da racionalidade e do senso comum. ${ }^{8}$ Em sua última retransmissão, a canção de

\footnotetext{
${ }^{8}$ Trata-se de cinco lunáticos - bobos e despossuídos da razão de diversos matizes -, uma criança e um cantador popular do sertão.
} 
Laudelim Pulgapé, explicita-se a questão de que aqui se trata: "[A Morte] Disse ao rei: - A tua sorte/ pode mais que o teu valor?" (ROSA, 1994, p.659) O problema aparece também, e talvez de forma mais destacada, em "A hora e a vez de Augusto Matraga", onde um valentão sertanejo enfrenta o altíssimo preço de lutar contra o que parecia o seu destino; em certo sentido, o protagonista alcança o seu intento, mas somente de forma muito relativa e problematizada, pois ao preço de sua morte.

Essas estórias questionam tanto a noção de destino, com sua carga semântica de determinação alheia ao sujeito, quanto a de liberdade individual. Causas externas que envolvem o sujeito em suas malhas são, sem dúvida, importantes na obra de Guimarães Rosa em geral e em Grande sertão: veredas em particular, como a crítica rosiana vem demonstrando - quer o faça por uma perspectiva histórico-sociológica ou mítico-metafísica. Entretanto, no que se refere aos elementos da realidade histórico social que contribuem na determinação dos caminhos dos personagens, eles não são os únicos, e sequer costumam ser os mais relevantes. O estudo de Alfredo Bosi, que foi discutido em alguns de seus aspectos neste trabalho, por exemplo, tem o mérito de demonstrar que as determinações sociais não o são exatamente, pois podem ser transpostas. Bosi observa que, em Primeiras estórias, algum tipo de superação da necessidade (ainda que ocorra somente "através de processos de suplência afetiva e simbólica" - BOSI, 1988, p.22) é possível. Para Riobaldo, isso também é verdade. E, no seu caso, a superação não se dá somente através de mecanismos simbólicos. O menino pedinte da venda do porto do De-Janeiro, como se sabe, tornou-se proprietário de terras e leva vida tranquila e confortável em sua fazenda às margens do São Francisco.

Quanto à outra ordem de determinações externas, as que provêm daquele mundo da divindade de que fala Bosi, elas, como já foi discutido aqui, são frequentemente problematizadas por
Riobaldo, que, apesar de buscá-las, não consegue se satisfazer com nenhuma explicação dessa natureza.

A liberdade individual também é problematizada pela força do acaso, que atua no sentido de construir uma concepção de travessia radicalmente aberta ao imprevisível. A vontade e a força da determinação pessoal de Riobaldo se impõem em diversos momentos. Talvez o melhor exemplo disso seja o fato de ele ter conseguido, como chefe Urutu Branco, transpor o até então intransponível Liso do Sussuarão e surpreender o bando do Hermógenes do outro lado. Existe no livro, como se sabe, a sugestão de que ele o tenha realizado com ajuda externa, a travessia acontece depois do suposto pacto com o demônio - e aí voltamos para o terreno do transcendente. Nada o livro autoriza afirmar, entretanto, que o pacto tenha de fato ocorrido. Riobaldo efetivamente se propôs a levar a cabo o projeto de se tornar pactário: foi para o local determinado, na hora certa, invocou o demônio e, depois disso, se transformou profundamente. Diadorim, que nada sabia do que havia acontecido, chegou a dizer ao então chefe Urutu Branco que algo havia se transformado no "cômpito de sua alma" (p.468) e que alguém lhe botara "malefício" (p.482). Isso, entretanto, não garante que o pacto tenha ocorrido. Riobaldo esperou durante toda a noite e nenhum diabo veio em pessoa ao seu encontro, nada aconteceu que denunciasse que ali um acordo com o sobrenatural estivesse sendo selado. A transformação de Riobaldo também não é garantia suficiente de que ele tenha feito um pacto com o demônio, pois pode ter ocorrido por autossugestão. Depois de passar uma noite tão extraordinária, seria natural que ele tivesse ficado impressionado com a situação e que isso tivesse influenciado seu comportamento. $\mathrm{Na}$ verdade, nada autoriza a afirmação de que o pacto tenha se dado, mas também não se pode afirmar o contrário; o livro deixa a questão em suspensão, como é muito comum ocorrer em Guimarães Rosa.

Outro aspecto importante o problema se revela quando se considera o propósito do pacto. O que Riobaldo mentalizou quando invocou o demônio 
("Acabar com o Hermógenes! Reduzir aquele homem!..." p.421) era o objetivo imediato do acordo com o demônio que o então jagunço se dispôs a fazer; mas há um outro, anterior a este. No trecho mesmo em que relata ter mentalizado que vendia sua alma em troca da morte do Hermógenes, Riobaldo parece ter dúvidas quanto ao objetivo principal do que fazia: "isso figurei mais por precisar de firmar o espírito em formalidade de alguma razão. Do Hermógenes, mesmo, existido, eu mero me lembrava". (p.421) Na verdade, tudo indica que ele tenha buscado a ajuda das forças demoníacas por Diadorim: eliminar o Hermógenes significaria libertar o companheiro da necessidade da vingança de Joca Ramiro para que eles pudessem, juntos, dar novo rumo a suas vidas. Riobaldo já havia proposto ao companheiro que deixassem o banco, e Diadorim, não só não se abalava da determinação de vingar Joca Ramiro, como se sentia afrontado com a proposta, e cobrava de Riobaldo lealdade e o cumprimento da palavra empenhada. Além disso, o bando atravessava situação delicadíssima: por ter de enfrentar, ao mesmo tempo, os hermógenes e os soldados do governo, e, sem líder a altura para conduzi-los nas dificuldades do momento, acabaram se embrenhando e se perdendo nos confins do sertão, e já vagavam há muito tempo sob o comando errático de Zé Bebelo, agora investido da condição de vingador de Joca Ramiro. Riobaldo, que talvez já viesse em certa medida se preparando para isso, ${ }^{9}$

\footnotetext{
9 Embora o desenvolvimento dessa questão não caiba nos limites desse trabalho, vale chamar a atenção, a esse respeito, para o fato de Medeiro Vaz, antes de morrer, ter indicado com os olhos Riobaldo para sucedê-lo; e outros também o fizeram, em outras situações. Há, entretanto, um episódio que marca em definitivo que Riobaldo está ficando cada vez mais próximo de assumir a chefia. Trata-se do episódio que se passa na Fazenda dos Tucanos, onde, sob o comando de Zé Bebelo, recém-investido da missão de vingar Joca Ramiro, o bando encontra-se cercado pelos hermógenes. Na ocasião, Riobaldo desconfia de que o plano de Zé Bebelo (avisar os soldados do governo da luta que ali se passava para que eles atacassem o bando rival e, enquanto isso, o bando sitiado aproveitaria a confusão para fugir a salvo de ambos os inimigos) escondia uma traição. Nesse momento, Riobaldo confronta o chefe, ameaça-o de forma mais ou menos velada, e toma a decisão de, caso se confirmassem suas suspeitas, matá-lo e assumir a chefia do bando. Em suas palavras: "Daí eu tomava o comandamento, o competentemente - eu mesmo! - e represava a chefia, e forçando os companheiros para a impossível salvação. Aquilo por amor do rijo leal eu fazia, era capaz; pelo certo que a vida deve de ser. (...) $E$ eu mesmo senti, a verdade duma coisa, forte, com a alegria que me supriu: - eu era Riobaldo, Riobaldo, Riobaldo! A quase que gritei
}

resolve tomar para si a responsabilidade de solucionar o impasse colocando-se à altura do adversário, que se acreditava pactário. O que ocorre, entretanto, é que, ao alcançar o objetivo intermediário, Riobaldo acaba por destruir a possibilidade de alcançar o objetivo último. A ironia trágica da situação está em que essa medida extrema, cujo objetivo final era ter alguma possibilidade de futuro com Diadorim, é que vai privar Riobaldo definitivamente do companheiro. Como o próprio ex-jagunço diz a certa altura, "Assaz o senhor sabe: a gente quer passar um rio a nado e passa; mas vai dar na outra banda é num ponto muito mais em baixo, bem diverso do que em primeiro se pensou. Viver nem não é muito perigoso?" (p.35) Nesse trecho, Riobaldo admite um certo grau de liberdade - é possível atravessar o rio se se toma essa resolução -, o que não é possível é prever a que lugares e situações essa resolução pode levar. O itinerário preciso não pode ser traçado; porque há a correnteza, os ventos, animais selvagens, sumidouros... e uma infinidade de coisas imprevisíveis, que nenhuma lista poderia jamais esgotar. Essa a terceira margem do rio, o lugar da irrupção do evento, do que "excede um determinismo, mas excede também os cálculos e as estratégias de meu domínio, minha soberania ou minha autonomia." (Derrida, 2004, p.69)

Essas são algumas das dificuldades que encontra o projeto logocêntrico de Riobaldo, que, a despeito de sua vontade e de seus esforços, frustrase reiteradamente, pois o que ele costuma encontrar é indeterminação e insegurança. No início deste trabalho, foi citado um trecho do Grande sertão onde o ex-jagunço afirma que gostaria de "decifrar as coisas que são importantes", entre elas a motivação profunda dos atos humanos, "a gã que empurra a gente para fazer tantos atos, dar corpo ao suceder". O verbo decifrar indica que Riobaldo supostamente acredita que uma cifra o impeça de alcançar esse

aquele este nome, meu coração alto gritou. Arre então, (...), eu estive todo tranquilizado e um só, e insensato resolvido tanto, que mesmo acho que aquele, na minha vida, foi o ponto e ponto e ponto." (p.468) 
entendimento: existiria uma verdade última, mas ela se esconderia por trás de uma floresta de signos que seria possível desbravar. O que ele também demonstra perceber recorrentemente é que não é possível decifrar as tais coisas importantes porque elas não são cifradas; na verdade, elas são incapturáveis em qualquer esquema explicativo de ordem racionalista, consensual ou transcendental. Grande sertão: veredas está o tempo todo a dizer que nenhum esquema binário, nenhum sistema lógico, nenhuma metafísica resiste na experiência da travessia.

\section{Referências}

BENNINGTON, Geoffrey. Jacques Derrida. Por Geoffrey Bennington e Jacques Derrida. Trad. Anamaria Skinner. Rio de Janeiro: Jorge Zahar Ed., 1996.

BOSI, Alfredo. Céu inferno. In: Céu inferno: ensaios de crítica literária e ideológica. São Paulo: Ática, 1988.

BRUYAS, Jean-Paul. Técnica, estruturas e visão em Grande sertão: veredas. In: COUTINHO, Eduardo (Org.). Guimarães Rosa. Rio de Janeiro: INL / Civilização Brasileira, 1983. p. 458-477. [Coleção Fortuna Crítica 6]

DELEUZE, Gilles. Crítica e clínica. Trad. Peter Pál Pelbart. São Paulo: Ed. 34, 1997.

DELEUZE. Lógica do sentido. $5^{\mathrm{a}}$ ed. Trad. Luiz Roberto Salinas Fortes. São Paulo: Perspectiva, 2009.

DELEUZE, Gilles; GUATTARRI, Félix. O que é a filosofia? Trad. Bento Prado Jr. e Alberto Alonso Muñoz. Rio de Janeiro: Ed. 34, 1992.
DERRIDA, Jacques. A escritura e a diferença. Trad. Maria Beatriz Marques Nizza Da Silva. São Paulo: Perspectiva, 2005.

DERRIDA, Jacques. Força de lei. Trad. Leyla Perrone-Moisés. São Paulo: Martins Fontes, 2007.

DERRIDA, Jacques. Gramatologia. Trad. Míriam Schnaiderman e Renato Janini Ribeiro. São Paulo: Perspectiva / EDUSP, 1973.

DERRIDA, Jacques; ROUDINESCO, Elisabeth. De que amanhã.... Diálogo. Trad. André Telles. Rio de Janeiro: Jorge Zahar Editor, 2004.

EAGLETON, Terry. Teoria da literatura: uma introdução. Trad. Waltensir Dutra. São Paulo: Martins Fontes, 1997.

FOUCAULT, Michel. A arqueologia do saber. 7a ed. Trad. Luiz Felipe Baeta Neves. Rio de Janeiro: Forense Universitária, 2010.

GARBUGLIO, José Carlos. A estrutura bipolar da narrativa. In: COUTINHO, Eduardo (Org.). Guimarães Rosa. Rio de Janeiro: INL / Civilização Brasileira, 1983. p. 422-423. [Coleção Fortuna Crítica 6]

LYOTARD, Jean-François. Imaginação e paradoxo. Discurso. n.10, p.175-190, maio 1979.

NUNES, Benedito. A Rosa o que é de Rosa: literatura e filosofia em Guimarães Rosa. Org. Victor Sales Pinheiro. Rio de Janeiro: Difel, 2013.

ROSA, João Guimarães. Grande sertão: veredas. Rio de Janeiro: Nova Fronteira, 2006.

ROSA, João Guimarães. Ficção completa. Rio de Janeiro: Nova Aguilar, 1994. v.1.

SOARES, Claudia Campos. A impossibilidade da fixação do sentido das coisas e da linguagem. In: O eixo e a roda: v. 23, n. 1, 2014, p.165-187.

\section{COMO CITAR ESSE ARTIGO}

SOARES, Claudia Campos. Ponteando opostos e especulando ideia: Riobaldo e a angústia da falta de sentido. Signo, Santa Cruz do Sul, v. 42, n. 74, p. 163-173, jun. 2017. ISSN 1982-2014. Disponível em: <https://online.unisc.br/seer/index.php/signo/article/view/7275>. Acesso em: http://dx.doi.org/10.17058/signo.v42i74.7275. 